Institute of $\mathbf{F}_{\text {ood and }} \mathbf{A}_{\text {gricultural }} \mathbf{S}_{\text {ciences }}$

\title{
Environmental Acts and Regulatory Agencies Affecting Citrus Groves in Florida ${ }^{1}$
}

\author{
Michael T. Olexa, Brian J. Boman, and Scott L. Hall ${ }^{2}$
}

\section{Introduction}

This document is intended to provide an understanding of the myriad of statutes, acts, and regulations affecting surface and groundwater that may be pertinent to a citrus grove in Florida. The laws governing water issues are a confusing array of overlapping, unclear, and occasionally even contradictory mandates. Since statutes and regulations and their interpretations are subject to change, this document should not be regarded as the final word on any of the topics discussed. The reader should view this publication as a means to determine the areas in which to seek more information.

In general, state law fills the gaps and supplements federal law. However, state law also often duplicates federal law and in many instances state standards are stricter than federal standards. Consequently, compliance with state law often assures compliance with federal laws.

State law takes two forms: statutes and administrative rules.
- Statutes are passed by the state legislature and set out the basic goals of the legislature and the procedures it wants applied to accomplish these goals. Although statutes often provide fairly specific directions or prohibitions, many details of regulating an area of business or an aspect of the environment are frequently too technical and minute for the legislature to address.

- The legislature will generally rely on administrative agencies to carry out the specific goals of the legislature. To do so the legislature empowers administrative agencies to adopt rules (which have the force of law) within the narrow bounds of their directive from the legislature. For example, if the legislature decided there was a state interest in regulating the use of certain pesticides, it might pass a statute that broadly outlines pesticide uses or prohibitions, then leave it to an agency (in this instance the Department of Agriculture and Consumer Services) to make rules about when, by whom, and in what quantities the pesticide must be applied. In most instances, agencies also have the power to enforce their rules through both criminal and

1. This is document No. CH161 and Circular 1423, one of a series of the Agricultural and Biological Engineering Department, Florida Cooperative Extension Service, Institute of Food and Agricultural Sciences, University of Florida. Publication date: September 2002. Please visit the EDIS Web site at http://edis.ifas.ufl.edu for additional publications related to citrus water management. This document can be accessed as http://edis.ifas.ufl.edu/CH161.

2. Michael T. Olexa, Professor, Food and Resource Economics Department; Brian J. Boman, Associate Professor, Department of Agricultural and Biological Engineering, Indian River REC-Ft. Pierce; and Scott L. Hall, Levin College of Law. University of Florida, Cooperative Extension Service, Institute of Food and Agricultural Sciences, Gainesville, FL 32611.

The Institute of Food and Agricultural Sciences is an equal opportunity/affirmative action employer authorized to provide research, educational information and other services only to individuals and institutions that function without regard to race, color, sex, age, handicap, or national origin. For information on obtaining other extension publications, contact your county Cooperative Extension Service office. Florida Cooperative Extension Service/Institute of Food and Agricultural Sciences/University of Florida/Christine Taylor Waddill, Dean. 
civil penalties as well as through

permitting/licensing regulations.

Typically, permits may be required from each of the following agencies when developing a citrus grove in Florida:

- County or local municipality.

- Local Water Control District.

- Regional water management district.

1. Surface water management/natural resources.

2. Consumptive use of irrigation water.

3. District right-of-way permit.

- Florida Department of Environmental Protection (FDEP).

- U. S. Corps of Engineers.

- Florida Department of Transportation (FDOT) for drainage or access rights.

Additional information on permits, regulations, statues, and requirements by various agencies can be found online via the Handbook of Florida Water

Regulations at:

http://edis.ifas.ufl.edu/ TOPIC_BOOK_Handbook_of_Florida_Water_Regul ations

In addition, information on water management district permits for citrus can be found in a document titled Water Management District Permits and Requirements for Florida Citrus Groves at:

http://edis.ifas.ufl.edu/CH192.

\section{Federal Acts}

The federal regulations of primary interest to Florida citrus growers include the following:

- Federal Insesticide, Fungicide and Rodenticide Act.
- Safe Drinking Water Act.

- Comprehensive Envrionmental Response, Compensation, and Liability Act.

- Resource Conservatrion and Recovery Act.

- Clean Water Act.

- Toxic Substances Control Act.

- Endangered Species Act.

Each act is summarized in the following sections.

\section{Federal Insecticide, Fungicide and Rodenticide Act}

The Federal Insecticide, Fungicide, and Rodenticide Act (FIFRA) was originally passed in 1947 and significantly amended in the 1970s and in 1988 to regulate all phases of pesticide sale, use, handling, and disposal. A pesticide is broadly defined within the meaning of the Act as any substance used to regulate, prevent, repel, or destroy any pest or plant. For the purpose of FIFRA, the term pest includes insects, rodents, nematodes, fungus, weeds, terrestrial and aquatic plants, viruses, and bacteria. It also may include other living organisms that the Environmental Protection Agency (EPA) designates as pests.

FIFRA is administered by the EPA, but the Act specifies that states are to have primary enforcement responsibility if they demonstrate to the EPA that they have adopted adequate regulations and enforcement mechanisms. Florida has entered into several cooperative agreements with the EPA, and now shoulders the responsibilities for testing and training permit applicants. In these areas, the EPA now has only a supervisory role. However, the registration of pesticides and the monitoring of pesticide producers is still regulated entirely by the EPA's central office. States may impose additional conditions on pesticide use where special problems related to their use are encountered.

There are two broad classes of pesticides: general-use and restricted-use. General-use pesticides may be applied by anyone and no permit is 
required, although the user must still comply with labeling requirements and other regulations. Restricted-use pesticides may be applied by three different categories of applicators:

- Private applicators who apply pesticides in producing an agricultural commodity on their own lands or on lands under their control. Applicators must be aware of regulatory restrictions to avoid adverse effects on the environment. Additionally, private applicators must be licensed to use pesticides.

- Commercial applicators who apply pesticides to other peoples lands in exchange for a fee. Commercial applicators are also required to be licensed.

- Experimental use applicators, who are usually manufacturers or researchers, are required to have an experimental-use permit to test an unregistered pesticide in order to gather data to support its registration.

Furthermore, restricted-use applicators must keep records comparable to commercial applicators. Also, the State may require specific minimum training for all applicators. Each permitting category is subject to separate testing and certification procedures, and may be subject to different penalties for violations.

\section{Safe Drinking Water Act}

The Safe Drinking Water Act (SDWA) was passed in 1974, and has been amended several times to expand both its breadth and the EPA's power to enforce it. The Act's primary purpose, which is to stop organic chemicals from entering drinking water systems, is accomplished by establishing quality standards for drinking water, monitoring public water systems, and guarding against groundwater contamination from injection wells. For example, under the Act no hazardous waste may be disposed of by underground injection within $1 / 4$ mile of underground drinking water. Injection wells usually imply very deep wells. However, the definition of injection under the Act may encompass several types of runoff, including irrigation return flow that enters the groundwater. Regulatory agencies, therefore, regulate the activity of the injection wells and not the wells themselves.

In Florida, the EPA has delegated enforcement of the SDWA to the state, and now only supervises the state programs approved to take its place. The 1986 amendments to the Act, however, gave the EPA increased authority to step in and enforce the Act if the state takes no action within 30 days of receiving notice from the EPA that water quality standards of the Act have been violated. The states must also adopt all new and revised national regulations in order to retain primary enforcement powers.

\section{Comprehensive Environmental Response, Compensation and Liability Act}

The Comprehensive Environmental Response, Compensation and Liability Act (CERCLA or Superfund) was passed in 1980 and amended in 1986. It empowers and provides a trust fund for the EPA to investigate and clean up sites contaminated by hazardous substances. CERCLA also extends liability for site pollution to several tiers of potential defendants at once, and is a potent measure for forcing responsible parties to contribute to the costs of cleanup.

The EPA has created a list of hazardous substances which are covered by CERCLA regulations. The Act includes all hazardous substances or hazardous pollutants which are identified by the federal Resource Conservation and Recovery Act (RCRA), the Clean Air Act, or the Clean Water Act. The only express exclusions from CERCLA coverage are petroleum (although the EPA reserves the power to classify specific petroleum products as hazardous) and natural or synthetic gas.

The EPA is the chief enforcer of CERCLA. However, the EPA must consult with the relevant state and local officials before deciding upon remedies for pollution at federal facilities, especially where the facilities or the remedies chosen fall within the reach of state environmental law. The Administrator of the Act has authority to begin investigations whenever there is reason to believe that a release has occurred or may occur. The EPA, or a state or local authority acting under agreement with the EPA, may require the person or entity under 
investigation to provide them with information about the nature and handling of all hazardous materials on the site, as well as information related to the subject's ability to pay for the cleanup. The Act also authorizes entry at reasonable times to any site dealing with hazardous materials and further authorizes the taking of samples from the site.

Under CERCLA, owners may be held liable for contaminated groves, even if they purchased land without the knowledge of previously buried hazardous waste. This has been a source of great concern to land buyers, banks, and others on the verge of acquiring land. CERCLA requires that the location of any site containing hazardous materials be reported to the EPA. Prompt notification is also required after any spill or release of contaminated materials into the environment. In many cases, liability can be placed on both the present and past owners irrespective of culpability. However, the security interest exemption protects lenders (such as banks) from liability when the lender does not participate in the management of the facility. Furthermore, persons who apply pesticides that are registered under FIFRA will not be subject to liability under CERCLA if the pesticides are applied according to the label instructions.

Potential land purchasers may want to use a method such as an environmental audit to lessen the fear associated with CERCLA liability. Environmental audits are an evaluation of the land's condition and an appraisal of the consequent likelihood of the lender becoming subject to some type of enforcement lien which might impair the lender's security. Such a lien might arise, for example, from the liability CERCLA imposes upon owners for hazardous substances buried on their land. CERCLA is threatening even to innocent buyers, since it applies even if the pollution was left by a previous owner and the buyer had no knowledge of it.

\section{Resource Conservation and Recovery Act}

The Resource Conservation and Recovery Act (RCRA) is intended to be comprehensive authority for all aspects of managing hazardous wastes. Separate requirements apply for the following categories: generators, transporters, and facilities for treatment, storage, or disposal of hazardous waste. These requirements, which include permitting for many facilities and exhaustive record keeping for all phases of management, are intended to track the movement and handling of the waste until it reaches its final point of disposal. This is known as the "cradle to grave" approach of monitoring wastes.

The Act also sets out standards for the disposal of solid wastes which includes wastes resulting from agricultural operations. However, irrigation return flow or pollutants covered as point sources under National Pollutant Discharge Elimination System (NPDES) permits of the Clean Water Act are not considered solid wastes. Therefore, they are not subject to RCRA's disposal standard.

The EPA is responsible for implementing and enforcing RCRA, for establishing the criteria for classifying hazardous wastes, and for listing the wastes for which the Act applies. The Act also permits states to enact their own hazardous waste programs which a state, instead of the EPA, may enforce. In order for a state to act in lieu of the EPA, the state acts must be at least as strict as the EPA regulations and must be approved by the EPA. Florida is authorized to administer all aspects of RCRA's base program which includes all facets of the Act which were passed before 1986.

Permits are required under RCRA for anyone who owns or operates a facility for the treatment, storage, or disposal of hazardous wastes. Generators and transporters may operate without an EPA permit, but must obtain an identification number and may be required to file reports with the EPA at regular intervals depending upon the quantity and type of wastes they handle. Additionally, the EPA retains broad authority to require tests, inspections, or additional monitoring when it determines there is an enhanced danger to health or the environment from the facility. This is especially true with regard to permitted hazardous waste facilities. Conversely, no federal permits are required for solid-waste disposal although there are federal regulations on the subject. 


\section{Clean Water Act}

The Clean Water Act is directed at maintaining and restoring the quality of navigable waters within the United States. Navigable waters include large to small bodies of water, as long as they have even a remote potential to affect interstate commerce or people involved in interstate commerce. Wetlands are also included, and are defined as lands periodically covered with enough water to support vegetation associated with wetland environments. The Act's purpose is to limit the amount of pollutants which may be released into these waters in an attempt to keep the waters safe for a variety of users as well as for fish and aquatic life.

Several agencies have responsibilities relating to the Clean Water Act. The Act in general is enforced by the EPA, but dredge and fill permitting is enforced by the Army Corps of Engineers. The EPA has established national standards for the maximum amount of pollutants which may be released under its permits. States are authorized under the Act to establish their own standards for allowable levels of pollutants, as long as such standards are at least as stringent as those mandated by the EPA.

Furthermore, the EPA may also delegate permitting authority to the state. Currently, Florida has been delegated enforcement of only portions of the Act.

The Act requires all operators of point sources of pollution to get permits. A point source can be any confined and measurable location from which a pollutant may be discharged. Point sources include pollutants that are discharged from ditches, rinsed pesticide containers, or any other source which releases pollutants into a specific area. Agricultural stormwater discharges and irrigation systems are considered nonpoint sources and are not covered by the Act. NPDES permits are the main avenue for the enforcement of this Act. These permits specify the amount and concentration of pollutants the holder is authorized to discharge, direct when compliance must be achieved, and specify the requirements for testing and reporting to the permitting authority. In Florida, NPDES permitting is conducted by the EPA as it has not been delegated to the state.
The NPDES permits impose two types of limitations on point-source polluters:

- Technology-based effluent limitations set limits on the contents of the effluent based upon the available treatment technology.

- Water-quality-based effluent limitations depend on the standards established for the quality of the water body (including groundwater bodies) into which the discharge takes place. These cases are viewed on a case by case basis.

The Clean Water Act requires separate permits for the discharge of dredge and fill material into navigable waters or wetlands. Dredge and fill permits are issued by the Corps of Engineers, but the EPA has a veto power over Corps issued permits. The EPA may enforce permits issued by the Corps or those issued by the state.

\section{Toxic Substances Control Act}

The Toxic Substances Control Act (TSCA) of 1976 governs the manufacturing, disposal, importing, distributing, and processing of all toxic chemicals. TSCA requires that all such chemicals be inspected and approved by the EPA before they enter the market. The EPA generally requires the manufacturer to gather data to determine if the chemical represents a threat to health or the environment prior to approval. The EPA has the option to limit the use of any chemical if toxological tests warrent restrictions on use.

TSCA does not cover pesticides (which are covered by FIFRA) and chemicals which are covered by the Federal, Food, Drug, and Cosmetic Act. All other chemicals, if they are not already on the EPA's approval list, are subject to review before they are released into the stream of commerce. The Act specifically dictates that the EPA create restrictions for Polychlorinated Biphenyls (PCBs), the only chemical identified by name as part of the mandate of TSCA.

The EPA is the sole authority for enforcement of TSCA, although the Act specifically provides that the states are not prohibited from enacting their own legislation to regulate chemicals. The Act limits the 
states' power only to the extent that the states may not test new chemicals if the EPA is testing for the same purpose. Additionally, the states are restricted in creating different requirements than those mandated by the EPA concerning chemicals that have already been regulated.

The Act also gives the EPA power to enforce its provisions by injunctions, restraint orders, forced inspections, and seizure of a product, as well as other means. In addition, courts have the power to restrict use of a product or impose specifications on how the material may be used in order to enforce TSCA. The EPA may also require cleanup of areas where violations resulted in environmental damage.

\section{Endangered Species Act}

The Endangered Species Act (ESA) was passed in 1973 to protect fish, wildlife, and plants which are threatened with extinction, and also to protect the ecosystems that are determined critical to their survival. In many cases these ecosystems are wetlands, so that endangered species protection often mandates wetland protection.

The Act requires all federal agencies to consult with an appropriate federal department (i.e., Department of the Interior, USDA) to determine what effects its land use or other actions will have upon endangered species. The agencies are prohibited from taking any action that will threaten an endangered species unless the agency obtains a special waiver from a committee headed by the Secretary of the Interior.

Agency action might include the issuance of a permit to a private party, such as when the Corps of Engineers issues permits for dredge and fill activities. The Act also applies to private and state actions, although the prohibitions are slightly different. The ESA grants enforcement authority to the Secretary of the Interior, the Secretary of Commerce and the Secretary of Agriculture. However, the Secretary of Agriculture is limited to enforcement authority in cases regarding the importation or exportation of plants.

The ESA prohibits the taking of any endangered species. Taking under the ESA means killing, trapping, harassing, hunting, collecting, or harming the species in any way. The definition of taking has been extended by the federal courts to include the destruction of areas designated as critical habitats, where the destruction might reasonably be expected to result in a reduction in the number or distribution of an endangered species. Therefore, any adverse modification, as well as destruction of critical habitat, is restricted under the ESA.

The agencies administering the Act are authorized to grant exceptions, usually by way of limited permits, to the prohibitions against takings. Permits may be granted for scientific purposes, and in cases where the applicant became economically dependent upon the species before it was placed on the endangered species list. These permits are usually limited to allow takings for only one year following the designation of the species as endangered.

The Central Florida Ridge and other well drained sandy soils in Florida support unique flora and fauna with a high degree of endemism (species found only in these habitats). Due to the initial relatively sparse distribution of the habitat types associated with these soils and the rapid conversion of them to citriculture, housing development, golf courses and urban encroachment, many of the species unique to them have been listed as threatened or endangered by federal, state, and local agencies. Consequently those areas remaining in their natural vegetative state have many development limitations associated with the protection of listed species. Therefore, when selecting land for new citrus plantings, it is often beneficial to select land that has already been cleared for other purposes.

In the coastal Flatwoods areas, loss of existing, native, upland habitats is of concern in certain areas but generally land clearing regulations are far less restrictive than on the Ridge. In this regard (i.e., land clearing) many County Comprehensive Plans contain exemptions for bona fide agricultural operations. When considering site selection for new grove in Flatwoods areas, it is still generally advantageous to procure already cleared land. 


\section{State Agencies Administering Acts}

The primary agencies in Florida administering statutes related to water are:

- Department of Agriculture and Consumer Services.

http://doacs.state.fl.us/

- Fish and Wildlife Conservation Commission. http://www.floridaconservation.org/

- Department of Environmental Protection. http://www.dep.state.fl.us/

- Water Management Districts.

SFWMD: http://www.sfwmd.gov/

SJRWMD: http://www.sjrwmd.com/

SWFWMD: http://www.swfwmd.state.fl.us/

The Florida Department of Environmental Protection (FDEP) has been directed to prepare the state water use plan and to foster interagency agreements to achieve the State Water Quality Plan. The water use plan is developed by FDEP through consultation with federal, state, and local agencies, and particularly the water management districts (WMDs). The plan includes all water in the state. Its main purpose is to allocate water use rights among various competing interests while retaining reasonable water quality and quantity control. Thus, the plan promotes the goals of environmental protection, proper drainage, flood control, and water storage.

\section{Department of Agriculture \& Consumer Services (FDACS)}

FDACS carries out functions related to farming practices and products. Responsibilities include the registration, labeling, and inspection of commercial fertilizers, and pesticides; registration of pesticide applicators; and soil and water conservation. Like the other state agencies, FDACS is divided into divisions, each with a separate concern. Among them are:
- The Division of Agricultural and

Environmental Services regulates and licenses pest control operators and provides assistance to the Soil and Water Conservation Districts.

Within this division is the Bureau of Pesticides which registers pesticides and oversees pesticide programs that are related to the protection of ground water, farm workers, and endangered species. This division also includes the Bureau of Soil and Water Conservation.

- The Standards Division is responsible for petroleum and underground tank inspections. Its functions include testing fuel quality and assuring fuel dispenser, scale, and measuring device accuracy.

- The Division of Forestry manages forest resources. Within this division is the Bureau of Planning Services, which includes the Watershed Protection Section (WPS). The WPS offers professional hydrology services to the public and other state agencies. It is also responsible for developing the silviculture elements of the State Water Quality Plan. Most importantly, the WPS monitors impacts of water regulation on forestry and can assisting growers in managing forest resources.

- The Division of Administration provides support services to all other divisions. This division includes the Office of Agricultural Law Enforcement, which provides for the inspection of agricultural products.

\section{Fish and Wildlife Conservation Commission (FWCC)}

The FWCC was created in 1968 for the management, protection, and conservation of wild animal life and fresh water aquatic life. Some of the agency's activities include habitat improvement, research, inspection of construction and development projects, development of public recreational areas, running a conservation information service program, and updating the threatened and endangered freshwater aquatic and land species lists. Although the FWCC has jurisdiction over any fresh running waters of the state, the FDEP is the agency primarily responsible for enforcement of water regulations. 
Jurisdictional directives in this area are overlapping, as many agencies have been granted the authority to address this concern.

\section{Department of Environmental Protection (FDEP)}

The FDEP was created by the Florida Environmental Reorganization Act passed in 1993. Its primary responsibility is to preserve the environmental integrity of Florida's air and water. The following are some of the reponsibilities of the FDEP:

- The prmitting of dredging and filling in waters of the state.

- Point source discharges.

- Leaking underground storage tanks.

- Administering the Water Resources Act of 1972.

- Review of water control districts.

- Regulation of air, water, and noise pollution.

- Solid and hazardous waste management.

- Public drinking water supplies.

- Controlling noxious aquatic weeds.

- Regulation of injection wells and wells related to oil exploration.

- The prevention or cleanup of pollutant spills or discharges into inland waters or lands of the state.

- Administration of such federal acts as the Clean Water Act and the Safe Drinking Water Act within the state of Florida.

- Collecting scientific data and information regarding water resources.

The Department of Environmental Protection has specifically delegated to the water management districts (WMDs) power to administer and enforce the provisions of Chapter 373 of the Florida Statutes. DEP has also given authority to the Department of
Agriculture and Consumer Services (FDACS) to regulate certain open burning activities through the Division of Forestry.

\section{Water Management Districts}

The Florida Water Resources Act of 1972 was enacted following a severe drought in 1971 as part of a package of major environmental and land use bills. (The South Florida and the Southwest Florida Water Management Districts had been created earlier to address flooding and water shortage problems). The act provides for comprehensive water resource management and the division of the state into five Water Management Districts. The boundaries of the WMDs were established by hydrologic surface water runoff boundaries. The WMDs that govern water in Florida's citrus belt include the Southwest Florida Water Management District (SWFWMD), the St. Johns River Water Management District (SJWMD), and the South Florida Water Management District (SFWMD) The WMDs play a very significant role in the regulation of water use and natural resource protection. The WMDs' responsibilities include:

- Management of water and related land resources via promotion of conservation.

- Proper utilization of surface and groundwater resources.

- Regulation of dams, impoundments, reservoirs, and other structures to alter surface water movement.

- Combat damage from floods, soil erosion, and excessive drainage.

- Assisting local governments in developing comprehensive water management plans, particularly by providing data on water resources. To accomplish this, WMDs are authorized to perform various field investigations and to provide works for the beneficial storage of water.

- Maintenance of navigable rivers and harbors and the promotion of the health, safety, and general welfare of the people of the state. Directly attached to this general welfare consideration is the power to implement water shortage emergency plans. 
- Participation in flood control programs, and the reclamation, conservation, and protection of lands from water surplus or deficiencies.

- Maintain water management and use facilities of the district and determine the levels of water to be maintained in the district bodies of water. To do so, districts may establish minimum flows for their works and water courses below which further withdrawals would be significantly harmful to the water resources or ecology. This also involves the establishment of minimum water levels for surface water and groundwater.

Each district is autonomous, has ad valorem taxing authority and is run by a governing board.

WMD governing board powers include administering the permit programs of Chapter 373, Florida Statutes. Thus, WMDs are responsible for permitting wells, management and storage of surface waters, and issuing consumptive use permits (SFWMD and SJRWMD) or water use permit (SWFWMD). Each WMD has specific criteria detailing the types of activities that require permits, the contents of permit applications, the procedures that surround submission of an application, and areas specifically exempted from permitting requirements. The Governor and Cabinet, sitting as the Land and Water Adjudicatory Commission, have authority to review any order or rule of a WMD.

\section{Areas of Concern}

The focus of environmental regulation by both state and federal statues is aimed at protecting and preserving water resources in Florida. Specifically, the acts address the following:

- Groundwater protection.

- Wetland preservation.

- Pesticide contamination.

- Solid waste management.

- Storage tanks.

\section{Groundwater}

Groundwater is classified into four categories, based first on whether the water is potable (drinkable) or non-potable, and on the total of dissolved solids the water contains. Under the classification scheme, aquifers retain the highest protection and are known as G-1 waters. Class G-4 waters are non-potable, located in confined aquifers only, and receive the least amount of protection. Additionally, unconfined groundwater always receives more protection, as it is susceptible to contamination from another aquifer.

Maximum contaminant standards specify the maximum amount of particular contaminants that will be tolerated in a particular class of water. Maximum contaminant levels (Primary Drinking Water Standards) are generally in accord with the EPA standards contained in the Federal Safe Drinking Water Act. Permits will not be issued when maximum contaminant levels are exceeded by a discharge activity. Secondary standards are also monitored in new facilities for compliance.

\section{State Provisions}

Discharge of waste into state waters is prohibited unless permitted by a state agency. Because underground water is included in the definition of water, this also applies to groundwater. A discharge activity will not be permitted if contaminants reduce ground or surface water quality below the required DEP classification standard.

A contaminant is any substance which is harmful to plant or animal life. However, applications of chemicals for agricultural purposes such as to control insects and aquatic weeds are exempt. Additionally, these exempt chemical applications must be approved for the particular use by the EPA or DACS, application must be made according to the label, and state standards as well as the Florida Pesticide Law must be followed.

The Water Management Districts have the power to control consumptive uses of groundwater in areas of known groundwater contamination. In other words, through Florida Statutes Chapter 373, the WMDs can restrict consumptive use through 
permitting whenever contamination is found.

Furthermore, the EPA regulates stormwater discharges associated with agriculture. The EPA exempts, via permit, agricultural stormwater discharges and agricultural return flows composed entirely of return flow from irrigated areas. However, the EPA does not exempt agricultural return flows that are not composed entirely of return flows from irrigated agriculture.

\section{Federal Provisions}

Federal regulation of groundwater consists of a variety of statutory directives administered by a host of administrative agencies. More than 16 pieces of federal legislation have some effect on groundwater, or have the potential to affect activities and programs relevant to its use. The most important are:

- The most important piece of federal legislation relating to water quality is the Clean Water Act. The main purpose of the Act is to eliminate point source pollution of surface water. Groundwater is directly implicated due to the natural linkage of surface and groundwater resources. When a party pollutes surface water, there is a good chance that water movement via the hydrologic water cycle will result in groundwater that will be simultaneously contaminated (see Fig. 1).

- The National Pollutant Discharge Elimination System (NPDES) places flow limitations on recognizable point sources of water pollution (for example, a pipe, well, or leaking container). Currently, the EPA administers the program.

- The Safe Drinking Water Act establishes maximum contamination levels for drinking water and serves to protect sole source aquifers (aquifers whose main use is to provide drinking water). Perhaps most significantly, the Act monitors the underground injection of contaminants into groundwater used for the public drinking water supply. The Underground Injection Control (UIC) program is the vehicle used to protect underground sources of drinking water. The UIC program is delegated to Florida by the EPA.

\section{Surface Water}

Use of surface water is regulated in Florida by the Water Management Districts. The districts issue water use permits (WUP) to allocate water for reasonable beneficial uses for fixed periods of time (duration may not exceed 20 years). However, permits are generally issued for shorter durations because the districts have lacked the information needed to commit the resource for longer periods of time.

Surface waters in Florida are classified according to the use of the water (Table 1). Class I waters have the highest protection and are suitable for potable water supplies. Class V waters are the lowest classification and these waters are used for navigation in addition to utility and industrial purposes.

Table 1. Classes of Florida waters.

\begin{tabular}{||c|l||}
\hline \hline Class & \multicolumn{1}{|c||}{ Use } \\
\hline Class I & potable water supplies \\
\hline Class II & $\begin{array}{l}\text { shelfish propagation or } \\
\text { harvesting }\end{array}$ \\
\hline Class III & $\begin{array}{l}\text { recreation, propagation and } \\
\text { maintenance of a healthy, } \\
\text { well-balanced population of fish } \\
\text { and wildlife }\end{array}$ \\
\hline Class IV & agricultural water supplies \\
\hline Class V & navigation, utility, and industrial \\
\hline \hline
\end{tabular}

Applicants must present evidence on the quantity of water requested; the need, purpose, and value of the use; and the suitability of the use to the source. The method and efficiency of use, water conservation measures, and the practicality of reuse or the use of lower quality water are also considerations. Applicants must show the proposed use will not interfere with any presently existing legal use of water. The permitted amounts must also be consistent with the public interest. The public interest can be defined further through rule making by the FDEP and WMDs.

When groves are developed in the Flatwoods, they typically require very significant changes in 


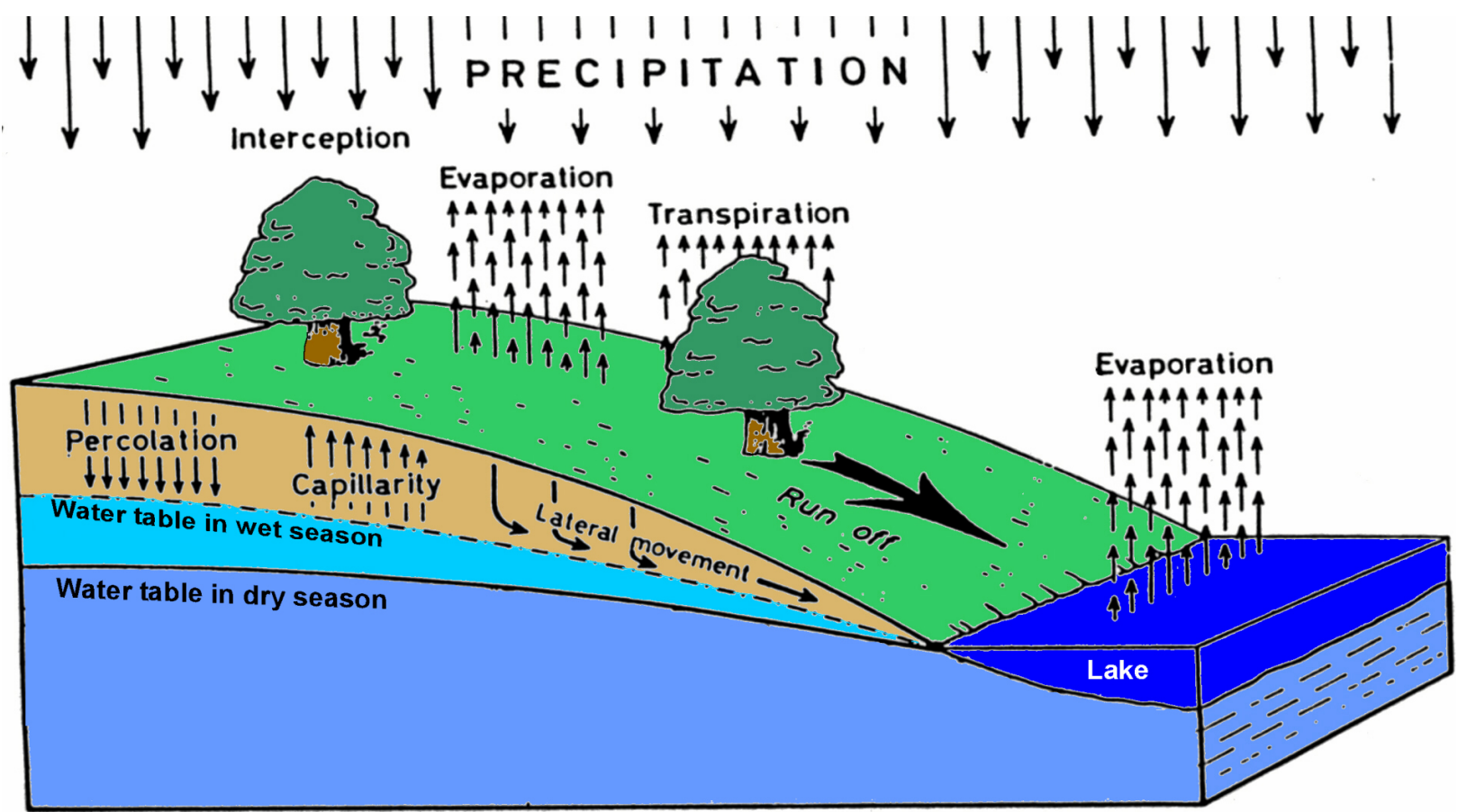

Figure 1. Typical hydrological cycle for Central Florida conditions.

water table levels and drainage from non-developed conditions. Therefore, the main resource protection concerns center around effects on wetlands and water quality. In addition changes to surface water discharge rates must be addressed to meet criteria adopted by the WMDs.

In order to obtain an Environmental Resource Permit from the appropriate WMD, a grove developer must either agree to provide on-going monitoring of discharge water quality or retain a professional engineer to design a system to meet the criteria for water quality treatment. In most cases this is achieved via detention areas. The detention areas provide attenuation of peak runoff rates and allow the drainage water to be released at lower rates over a longer period.

The U. S. Army Corps of Engineers (COE) regulates direct impacts to wetlands via the discharge or deposition of fill. The WMDs and the COE are also tasked with assessing and regulating secondary and cumulative impacts. It is important therefore to try to eliminate impacts to wetlands from proposed designs. The issues can be fairly complex to the extent that it usually becomes cost effective to retain consultants in the field to prepare designs and permit applications to address them.

\section{Wetlands}

Federal protection of wetlands stems from several sources. Under the Clean Water Act, the Corps of Engineers is authorized to issue permits for the discharge of dredge and fill material into waters of the United States. Coupled with this authority, and pursuant to the National Environmental Policies Act (NEPA), the Corps must complete an environmental assessment study before issuing a permit for work in sensitive areas, especially wetlands. If the Corps determines that the activity will have a significant impact on the wetlands, a more thorough environmental impact study will be required as well. As added checks on the Corps' authority to issue dredge and fill permits, the Corps is required to consult with other federal and state agencies whenever relevant and, by virtue of the Clean Water Act, the Administrator of the EPA retains the power to veto Corps issued permits at the EPA's discretion.

On the state level, the FDEP is primarily responsible for wetland protection. FDEP has been given authority to protect environmentally sensitive wetland areas and designated areas of critical state concern (prominent examples include the Florida Keys, Big Cypress Area, Green Swamp Area, the 
Everglades Protection Area and the Apalachicola Bay Area). In addition, the appropriate water management district should be consulted with regard to any work to be done near wetlands. The districts have adopted management and storage of surface water rules which regulate activities in wetlands under FDEP supervision. Also, the districts are authorized to establish specific permitting criteria for dredge and fill operations in connected and isolated wetlands.

For the purpose of Corp of Engineers permitting, wetlands include those areas with a prevalence of vegetation adapted to live in saturated soil conditions. With regard to the FDEP's jurisdiction, detailed indexes have been compiled to determine which soil and plant characteristics identify wetlands. On request, the Department of Environmental Protection or the appropriate water management district will issue declaratory statements for particular sites regarding whether or not its jurisdiction extends to that area. They also can issue formal or informal determinations as to the extent of wetlands. These declarations are valid for up to five years as long as physical conditions on the property do not change. The WMD's definitions of wetlands depend on hydrologic, vegetative and soil characteristics of an area.

Dredge and fill permits are required for any non-exempt activity. The first step in obtaining a permit is assuring FDEP (or the WMD) that state water quality standards will not be violated by the proposed dredging and filling activity. Second, the project cannot be contrary to the public interest. Several factors must be considered in this determination, including:

- effects on public health, safety, welfare, and property rights,

- effects on fish and wildlife (especially on threatened or endangered species),

- adverse effects on navigation,

- harmful erosion,

- effects on marine productivity,
- the temporary or permanent nature of the project,

- and effects on historical and archaeological resources.

In the final analysis, factors which mitigate destruction of the wetlands are also considered where some damage to the environment is inevitable. Duration of permits is generally for 5 years and does not exceed 10 years, unless the project cannot reasonably be completed within that time. In these exceptional circumstances, the DEP may issue 25-year permits.

Under federal regulations, normal farming, silviculture and ranching activities in wetlands are exempt from the fill permitting mandates of the Clean Water Act. This exemption does not apply to mechanized equipment used in land clearing, as this has been held to represent a point source of pollution. In Florida, generally speaking, agricultural activities and agricultural water management systems are exempt from wetland regulation provided that the activities are consistent with agricultural activities. Agricultural activities are defined to include all necessary farming and forestry activities which are normal and customary for a particular area provided such operations do not impede or divert the flow of surface waters. Agricultural water management includes farming or forestry water management systems and farm ponds which are permitted pursuant to Florida Statutes Chapter 373 or exempted from the permitting requirement of the surface water management statutes.

The Everglades Forever Act empowers the South Florida Water Management District to do the following:

- Adopt the Surface Water Improvement Management (SWIM) plan.

- Acquire land by eminent domain for treatment and storage of water prior to its release into the Everglades Protection Area.

- Create and administer a stormwater management system. 
- Develop, implement, and enforce plans and programs along with DEP for the improvement and management of the Everglades Protection Area.

\section{Pesticides}

The use of agricultural pesticides falls within the purview of several federal statutes as well as Florida law. Under federal law, pesticides are primarily regulated by the Federal Insecticide, Fungicide and Rodenticide Act (FIFRA). Many other federal statutes and agencies come into play, though, in more particular situations. Florida has passed additional legislation designed specifically to cover the use of pesticides, with enforcement authority vested primarily in the FDACS. Many of these laws and regulations are similar to those enacted by the federal government.

Pesticide labels have become a central tool for enforcement of both FIFRA and state law. Under FIFRA, users must comply with all the application and precautionary instructions on the label. In this sense, the label is the law. Failure to comply with the label can result in strict penalties. It is important to note that the farmer can be penalized even if an employee of the farmer was responsible for the failure to follow the label instructions. The Florida statutes excuse pesticide users from following the instructions on the label only to the extent that:

- The pesticide may be applied in lesser dosages, concentrations, or frequencies than recommended by the label.

- The pesticide may be used against a pest not specified as a target pest by the label, so long as the application is to a crop, animal or site specified by the label and the label does not prohibit the application.

- Applicators may employ any method of application not prohibited by the labeling.

- Applicators may mix the pesticide with a fertilizer when not prohibited by the labeling.

Under the federal Clean Water Act, any point source pollution of a navigable waterway must have a NPDES permit from the EPA. While irrigation return flow is exempted from this requirement, other agricultural polluting activities are not. For instance, a ditch containing fertilizers or pesticides entering navigable waterways is a point source of pollution, and is subject to the permitting requirements of this act.

Any pollutant introduced into a source of drinking water, including wells and aquifers, is subject to regulation under the Federal Safe Drinking Water Act. It should be mentioned that this act has been interpreted to cover irrigation return flow which seeps back into subsurface water as an underground injection if the flow carries any pollutants.

The FIFRA requirements for adherence to label instructions also extends to the storage and disposal of pesticides. Further, pesticides often fall within the hazardous waste classifications of RCRA, and are usually subject to solid waste disposal regulations. The RCRA or FIFRA sections of this publication should be reviewed before storing or disposing of any pesticides. The EPA provides guidelines for the storage and disposal of pesticides which, while not mandatory, are helpful in dealing with specifics of locating storage sites, protecting groundwater and other ways of avoiding environmental contamination.

Florida law requires that all irrigation systems which are used to administer crop management materials, such as pesticides or fertilizers, be equipped with antisyphon devices to prevent the backflow of pesticide- or fertilizer-contaminated water to the aquifer. These rules also apply to pesticides pre-mixed with fertilizer, although such mixtures must be clearly labeled as such before they may be offered for sale.

\section{Solid Waste Management}

Both Florida and the federal governments have enacted Resource Conservation and Recovery Act (RCRA) legislation to deal with the disposal of solid wastes. The state rules are administered by the DEP, and the federal rules by the EPA. Both RCRAs are aimed at protecting health and the environment and at recycling or reclaiming solid wastes to the greatest extent practicable. Because improperly handled solid waste represents such a grave threat to water quality, it also falls within the scope of other federal 
regulations, most notably the National Pollutant Discharge Elimination System (NPDES) of the Federal Clean Water Act. NPDES is an EPA and state-enforced system requiring permits for all point source pollution discharges into navigable waters.

Aside from the areas of special state and federal interest, local authorities are basically free to set their own rules, within broad state guidelines, for the collection and disposal of solid wastes. Cities, counties or municipalities should be consulted regarding problems involving the locations of disposal facilities, frequency of waste pickup, and other day-to-day waste disposal questions.

Solid waste has been defined as any garbage, refuse, sludge or other discarded materials, including liquid, semi-solid, or contained gaseous materials. Furthermore, waste from agricultural activities is expressly included. The only relevant materials which are expressly listed as not within the RCRA definition of solid waste are domestic sewage; waste from irrigation return flows; and point source discharges which are permitted for release under NPDES of the Clean Water Act. If none of these exceptions apply, and if the material involved may be said to be discarded or to have served its useful purpose, it is a solid waste. Solid waste may be recycled, reused, discarded, reclaimed or stored, depending on its nature. Many solid wastes may also be hazardous wastes, and therefore subject to other, more restrictive regulations. Therefore, the section on hazardous waste must also be consulted when considering solid wastes.

NPDES coverage extends only to discharges into navigable waters, and sets different standards for the amount of waste which may be discharged based upon the type of industry involved, the toxicity of the waste, and the acceptable maximum amounts of harmful elements which can be released into the body of water which is being polluted. Facilities which are disposing of wastes in any way not in accordance with the federal RCRA guidelines or NPDES requirements for discharging water are deemed to be violators of the law.

The FDEP has established detailed regulations controlling the application of sludge to land. Sludge is basically solid, liquid, or semi-solid waste generated from wastewater treatment plants, air pollution control facilities, septic tanks, grease traps, portable toilets or related operations, or any other waste having similar characteristics. This system requires all producers to have their sludge tested so that it may be classified as one of the three grades of sludge recognized by FDEP. (Grade I is the least hazardous, grade III, the most hazardous.)

No permit is required to apply sludge to the land of the sludge generator as long as the sludge is treated for bacteria and insect infestation and handled in accordance with FDEP rules. No permit is required for normal farming operations, which include the application to farm land of grade I domestic, grade I composite sludge, domestic septate which has been properly treated to kill microorganisms, or food service sludge.

The application of grade II sludge is not a normal farming operation under the rules. Since grade III sludge must generally be disposed of where it will have the least harmful effect on the environment, it is unsuitable for application to farm land. All uses which are not normal farming operations will require FDEP permits. The FDEP may require a general permit for application of less harmful sludge, but may require more restrictive permits (including solid waste disposal site permits) for the application or disposal of more harmful sludge.

\section{Storage Tanks}

Statewide regulation of stationary storage tanks is primarily the domain of the FDEP. The Pollutant Discharge Prevention and Control Act gives the FDEP the power to regulate pollutant storage tanks. Subsequently, most of the rules covered in this section are those of the FDEP. It is important to note, however, that the regulations allow individual county governments to promulgate their own regulations. These local regulations can be more stringent than those of the FDEP. County authorities should be consulted even if the storage tank activity or condition is apparently within the statewide standards.

A tank will fall within the scope of the regulations if it holds a pollutant. A pollutant is defined as any type of oil or gasoline; any pesticide; 
or any ammonia or chlorine compound or derivative. The bulk of the regulations only apply to storage tank systems whose individual storage capacity is greater than 110 gallons. Tanks smaller than this need only comply with the general requirement that they do not discharge their contents into the environment, and that they conform to fire prevention standards.

Twenty-one types of storage tank systems are on a list that makes them exempt from this Act. For example, any agricultural storage tank system of 550 gallons or less capacity is exempt. For the most extensive and updated list, check with FDEP. The FDEP makes important distinctions between new tanks and those which were already in operation before 1992. New tanks are subject to the strictest safety standards, but existing tanks must be brought into compliance with many of the same standards for overfill protection, monitoring systems, and tank linings within a given period. The time allowed for this retrofitting varies depending upon the year the tank was installed, but the FDEP contemplates the complete retro-fitting of all existing tanks by 2009 .

Aboveground systems are subject to less restrictive regulation, and are subject to this chapter if they have a storage capacity greater than $\mathbf{5 5 0}$ gallons. (An aboveground tank has no more than 10 percent of its volume buried, including integral piping.) These tanks, however, are subject to similar record keeping rules as buried tanks and must be equipped with an impervious containment barrier to catch spills. Further, any part of the tank in contact with the ground must be protected against corrosion.

Operators of storage facilities are required to keep records for DEP inspection. These records must include the results of all tests and inspections, as well as maintenance and inventory notes on the tanks or their contents. The records must date back at least two years and must be made available to the DEP within five working days notice.

\section{Litigation}

In addition to direct action from regulatory agencies, citrus growers may sometimes face private lawsuits relating to water quality issues. Some federal laws have clauses that allow citizens to enforce the federal laws. It is important to understand how one may be held liable for actions by the public.

Lawsuits are often based on the nuisance and negligence principles of law. Nuisance, which is defined as using one's property in a way that causes harm to others, is a common basis for pollution litigation. Nuisances are categorized as either public or private, depending upon whether the nuisance affects the rights of the public or only the rights of an individual. Public nuisance actions may be brought by a public official on behalf of the public at large, and certain types of public nuisances may be criminal acts. In nuisance actions, the court will often balance the social value of the nuisance against the harm it causes. If the harm is slight and the social value is great, the suit will fail. But if the social value is small and the harm is great, the plaintiff may recover monetary damages and prohibit the defendant from continuing the activity.

The Florida Right-to-Farm Act restricts nuisance suits against farmers by providing that no farm, which was not a nuisance when it was established, will constitute a public or private nuisance after one year of operation. Change of ownership does not affect the provisions of the Act. This does not give the farmer a license to violate the principles of negligence or nuisance. Therefore, contaminating a water well or misapplying pesticides will still open the farmer up to a potential law suit. Additionally, the Act does not extend protection to unsanitary conditions or health hazards, or changes of use, either in type or intensity.

Negligence basically means causing harm to someone else by failing to do what a reasonable person would have done under the same circumstances. The harm may be economic, physical, or emotional. Anyone seeking to recover for someone else's negligence must prove four legal points: duty, breach of duty, causation of damage, and value of damage.

- Duty is an individual's responsibility to govern his or her own conduct so that others are not harmed.

- Breach of duty occurs where one of the parties does not fulfill his duty of care. That is, he does not act with the degree of caution 
or foresight that a reasonably prudent person would have used in the same situation.

- Causation is that the defendant's failure to use due care was the cause of the plaintiff's harm. Proving this step may be difficult if the damage is only indirectly related to the defendant's act, or if there are other possible causes for the harm.

- The plaintiff must prove that he/she suffered actual damage from the defendant's act. If no damage resulted, even where the defendant's conduct was admittedly negligent, the plaintiff has no claim for negligence.

Where a defendant's acts subject him/her to private suit and, at the same time, violate a statute, the court will usually regard the violation of the statute as enough evidence of wrongful conduct to find the defendant guilty of negligence in the private suit as well. This rule applies, however, only if two conditions exist. First, the damage asserted in the lawsuit is of the type the statute is intended to prevent. Second, the plaintiff is a member of the class of persons the statute is intended to protect. It should be noted that compliance with all statutes does not guarantee immunity from negligence actions, as lawful behavior may still be negligent.

Strict liability means liability imposed without evidence of negligence. That is, the defendant may be found guilty upon proving that his/her actions caused harm, without consideration of whether or not he/she acted reasonably. Strict liability is usually imposed upon those who engage in abnormally dangerous or hazardous activities, like handling explosives, or other activities defined by statute, e.g. CERCLA.

Where two or more parties, acting independently, are the source of a plaintiff's injuries, the law (or the courts) may impose the principle of joint and several liability. This principle allows the plaintiff to recover from either defendant the full amount of damages, and the defendants are forced to apportion the cost among themselves.

\section{References}

Olexa, M. T. 1991. Handbook of Florida water regulation. Univ. of Florida, IFAS Coop. Ext. Serv. Circ. 1026.

\section{Glossary}

CERCLA: Comprehensive Environmental Response, Compensation and Liability Act (Superfund)

COE: U. S. Army Corps of Engineers

CWA: Clean Water Act

EPA: Environmental Protection Agency

ESA: Endangered Species Act

FAC: Florida Administrative Code

FDACS: Florida Department of Agriculture and Consumer Services

FDEP: Florida Department of Environmental Protection

FDOT: Florida Department of Transportation

FIFRA: Federal Insecticide, Fungicide and Rodenticide Act

FWCC: Fish and Wildlife Conservation Commission

FWPCA: Federal Water Pollution Control Act

NEPA: National Environmental Policy Act

NPDES: National Pollutant Discharge

Elimination System

RCRA: Resource Conservation and Recovery Act

SDWA: Safe Drinking Water Act

SWIM: Surface Water Improvement Management

TSCA: Toxic Substances Control Act 
UIC: Underground Injection Control

USDA: United States Department of Agrculture

WMD: Water Management District

WPS: Watershed Protection Section

WUP: Water Use Permit 